\title{
VIABILITY OF MAMMARY BOVINE LEUKOCYTES CHALLENGED WITH ANTI-MASTITIS DRUGS
}

\section{VIABILIDADE DE LEUCÓCITOS MAMÁRIOS BOVINOS DESAFIADOS COM DROGAS ANTI-MASTITE}

\author{
Camila Freitas Batista ${ }^{1^{*}}$ \\ Renata Caminha Gomes ${ }^{1}$ \\ Maiara Garcia Blagitz ${ }^{2}$ \\ Alice Maria Melville Paiva Della Libera ${ }^{1}$ \\ ${ }^{1}$ Faculdade de Medicina Veterinária e Zootecnia da Universidade de São Paulo, São Paulo, SP, Brazil. \\ 2Universidade Federal da Fronteira Sul, Realeza, PR, Brazil. \\ *Author for correspondence - camilafb@usp.br
}

\begin{abstract}
The occurrence of viable cells in mammary gland secretions attests the functionality of the defense system. This fact, along with applied medicine, is fundamental for the healing udder. The objective of this study was to evaluate the in vitro viability of milk leukocytes challenged with four intramammary anti-mastitis drugs. We collected eight cow milk samples that were negative after a bacteriological examination. Cell suspensions were submitted to an evaluation of viability through Trypan Blue exclusion before and after incubation with the drugs. Mean pre-incubation viability rate $( \pm$ standard deviation) of milk cells was $50.17 \%( \pm 6.50)$. Mean post-incubation viability rates ( \pm standard deviation) of control group (devoid of any drug), Drug 1 (anhydrous cephalonium), Drug 2 (gentamicin), Drug 3 (procaine benzylpenicillin associated with dihydrostreptomycin nafcillin), and Drug 4 (benzathine cloxacillin) were, respectively, $31.36 \%( \pm 3.61) ; 26.23 \%( \pm 4.49) ; 7.82 \%( \pm 2.33) ; 3.10 \%( \pm 0.94)$; and $30.33 \%( \pm 4.14)$. The uppermost impairments were found when milk cells were challenged with Drug 2 and Drug 3. Although antimicrobial activity of tested drugs was not appraised, and a single aspect of cell function was tested, we concluded that treatments 2 and 3 could impair the functionality of milk leukocytes and could provide an ineffective immunological response, and an effective response is essential to control mammary infections.
\end{abstract}

Keywords: cow; cell cytotoxicity; mammary gland; milk.

\section{Resumo}

A ocorrência de células viáveis em secreções das glândulas mamárias atestam a funcionalidade do sistema de defesa. Este fato, juntamente com o medicamento aplicado, é fundamental para a cura do úbere. O objetivo deste trabalho foi avaliar a viabilidade in vitro de leucócitos do leite desafiados com quatro drogas anti-mastite intramamárias. Foram coletadas oito amostras de leite de vaca negativas no exame bacteriológico. As suspensões de células foram submetidas à avaliação da viabilidade pelo método de exclusão do Azul de Trypan pré-incubação e pós-incubação com os medicamentos. A taxa média de viabilidade pré-incubação ( \pm desvio-padrão) das células do leite foi $50,17 \%( \pm 6,50)$. As taxas médias de viabilidade pós-incubação ( \pm desvio-padrão) de grupo controle (desprovido de qualquer droga), Drogas 1 (cefalônio anidro), 2 (gentamicina), 3 (benzilpenicilina procaína associada a diidroestreptomicina naficilina) e 4 (cloxacilina benzatina) foram, respectivamente, $31,36 \%( \pm 3,61)$; $26.23 \%( \pm 4,49) ; 7,82 \%( \pm 2,33) ; 3,10 \%( \pm 0,94)$; e $30,33 \%( \pm 4,14)$. Os maiores prejuízos foram encontrados quando as células do leite foram desafiadas com as drogas 2 e 3. Embora a atividade antimicrobiana das drogas testadas não tenha sido avaliada, e um único aspecto da função das células tenha sido testado, concluiu-se que os tratamentos 2 e 3 poderiam prejudicar a funcionalidade de 
leucócitos do leite e fornecer uma resposta imunológica ineficaz, e uma resposta eficaz é indispensável para controlar as infecções mamárias.

Palavras-chave: citotoxicidade celular; glândula mamária; leite; vaca

Received on: October $5^{\text {th }}, 2015$

Accepted on: June, $17^{\text {th }}, 2016$

\section{Introduction}

The mammary gland has its own defense mechanisms to combat local infection. The cells that act in the first line of antibacterial defense are the polymorphonuclear leukocytes and the macrophages, and they are essential to eliminate the pathogens ${ }^{(1,2)}$. These cells' activity combined with some medication applicationcollaborate for the healing of the $\operatorname{udder}^{(3-6)}$.

Thereby, the use of antimicrobials is effective in the elimination of microorganisms ${ }^{(7-9)}$; however, its effects related to the viability of phagocytic cells have not been elucidated. We have to consider that to have therapeutic efficiency, the drugs must execute their functions without impairing cell survival. Some authors researched the action of some active principles on phagocytes with the hypothesis that there is a potential interference of the drug on the immune function that could decrease the therapeutic efficiency ${ }^{(10,11)}$. These authors concluded that the evaluation of the phagocytic function was submitted to many interferences ${ }^{(12)}$.

In order to preserve the function of phagocytes we must know how these widely used drugs interfere with their function so that we can effectively treat animals affected by the disease. The objective of this study was to evaluate the in vitro viability of milk leukocytes challenged with intramammary anti-mastitis drugs.

\section{Material and Methods}

Commercial drugs were used with the following active principles: anhydrous cephalonium (Drug 1), gentamicin (Drug 2), procaine benzylpenicillin associated with dihydrostreptomycin nafcillin (Drug 3 ), and benzathine cloxacillin (Drug 4). Eight milk samples were collected being negative at the bacteriological examination. Macroscopic evaluation of milk samples was made with a Tamis Test and milk cellularity was indirectly estimated with California Mastitis Test (CMT). Milk samples were centrifuged $\left(500 \mathrm{xg}\right.$, for 20 minutes, $\left.4^{\circ} \mathrm{C}\right)$. The more viscous supernatant formed in the mirror sample, consisting mainly of fat, was removed, or simply had their bottle edges taken off before reverting the content. After the fatty part was discarded, the supernatant was discarded by inverting the flask once, only preserving the knob of cells formed at the bottom of the flask. This knob was released by gentle spraying of PBS (approximately $2 \mathrm{~mL}$ of PBS per vial). The resuspended cell buds were transferred to another Falcon flask, homogenized, and the initial volume filled with refrigerated PBS $(50 \mathrm{~mL})$.

After a second centrifugation, the supernatant was discarded, the button formed detached and resuspended in $1 \mathrm{~mL}$ of enriched medium (RPMI 1640) to improve the conditions for its preservation.

Cell suspensions were submitted to viability evaluation through Trypan Blue exclusion test, an aliquot of $10 \mu \mathrm{L}$ of the cell suspension (resuspended cells in $1 \mathrm{~mL}$ RPMI 1640) was added to $90 \mu \mathrm{L}$ of Trypan blue solution $0.1 \%\left(\mathrm{MERCK}^{\circledR}\right)$ and the milk leukocyte count in Neubauer chamber quadrant of leukocytes in optical microscopy (OLYMPUS ${ }^{\circledR}$ microscope) with 400x, and adjusted to $2 \times 10^{6}$ cells $/ \mathrm{mL}$ before incubation. 
The total number of cells counted in leukocytes quadrant corresponds to the cell concentration of the cell suspension 1, which was expressed in number of cells counted x 105 cells / mL. For the execution of the tests the concentration of viable cells was calculated in order to obtain a suspension cells containing 2x106 cells/mL (cell suspension 2).

Anti-mastitis drugs were used for dry cows in cell suspension 2, previously diluted (1:1) in RPMI 1640 (the volume of the tube of the drug was diluted in an equal volume of RPMI 1640), namely anhydrous cefalonium (M1), gentamicin (M2), benzylpenicillin associated naficilin and dihydrostreptomycin (M3), an association between penicillin, semisynthetic penicillin and aminoglycosides; cloxacillin (M4) a semisynthetic penicillin. Subsequently, 1/100 of the dosage indicated to a mammary quarter, as recommended by the manufacturer, was added to adjusted cell suspensions.

The cell suspension 2 plus the drug was called cell suspension 3, and the cell suspension 2 was also used as a control group. Cell suspension 2 (control goup) and cell suspension 3 were kept at $37^{\circ} \mathrm{C}$ for an hour and for out further assessment of the viability of these cells.

To analyze the data, we used the Anderson-Darling tests to verify of normality, and the Mann-Whitney test and ANOVA to check the differences between the means obtained with an interval of $95 \%$ through software MINITAB ${ }^{\circledR}$ Release 14.1.

\section{Results and Discussion}

The efficiency of the drugs used to treat cows in the dry period and their action against microbiological agents is already known ${ }^{(7-9)}$; however, this efficiency is not necessarily related to the way these agents affect the activity of the mammary gland's defense cells ${ }^{(3,4)}$. Based in the hypothesis that the efficiency of an antimastitis drug, especially those indicated for the treatment during the dry period, does not depend only on their antimicrobial effect, the present study intended to evaluate the effect of the drug (antimicrobial and vehicle) on the cellular viability using the in vitro Trypan Blue exclusion technique.

Mean pre-incubation viability rate ( \pm standard deviation) of milk cells was $50.17 \%( \pm 6.50)$ (Table $1)$. Mean post-incubation viability rates ( \pm standard deviation) of control group (devoid of any drug), Drug 1, Drug 2, Drug 3, and Drug 4 were, respectively, 31.36\% ( \pm 3.61$) ; 26.23 \%( \pm 4.49)$; $7.82 \%( \pm 2.33) ; 3.10 \%( \pm 0.94)$; and $30.33 \%( \pm 4.14)$.

Table 1. Mean pre-incubation viability rate ( \pm standard deviation) and mean post-incubation viability rates ( \pm standard deviation)

\begin{tabular}{cccccc}
\hline Pre-incubation & \multicolumn{5}{c}{ Post-incubation } \\
\hline Control Group & Control Group & Drug 1 & Drug 2 & Drug 3 & Drug 4 \\
& & & & & \\
$50.17 \%^{\mathrm{a}, \mathrm{b}, \mathrm{c}}$ & $31.36 \%^{\mathrm{a}}$ & $26.23 \%^{\mathrm{a}}$ & $7.82 \% \%^{\mathrm{b}}$ & $3.10 \%^{\mathrm{c}}$ & $30.33 \%^{\mathrm{a}}$ \\
$( \pm 6.50)$ & $( \pm 3.61)$ & $( \pm 4.49)$ & $( \pm 2.23)$ & $( \pm 0.94)$ & $( \pm 4.14)$ \\
\hline
\end{tabular}

$\overline{a-c}$ Means within a row with different superscript letters differ among each other $(P<0.05)$.

Other authors that also investigated the effect of drugs on the mammary defense mechanisms ${ }^{(3,10-13)}$ used different techniques and preparations. Dosogne et al. ${ }^{(11)}$ did not verify an interference with the in vitro phagocytic capacity of blood phagocytes exposed to preparations of cephapirin and mecylinamin, demonstrating that these drugs do not affect the viability of cells, which is similar to the results found 
in this study with the use of anhydrous cephalonium.

These contradictions are not limited to different authors. In a study using twelve different antibiotic preparations, Nickerson et al. ${ }^{(10)}$ observed that most of the antibiotics produced deleterious effects on the phagocyte function. The same group, in 1986, carried out another study with three antibiotics and observed that PMN cells isolated from mammary glands treated with tetraciclin and gentamicin presented a reduction of the phagocytic activity, contradicting the study performed earlier as well as the present experiment. Another study carried out by the same team showed that gentamicin (Drug 2), one that reduced the leukocyte viability, caused a reduced functional activity of milk leukocytes ${ }^{(14)}$.

It has to be emphasized that comparisons with other studies are not exact, once technical differences, active principles, preparations, and vehicles present in drugs can potentially influence the results obtained.

\section{Conclusion}

Results show that all treatments decreased milk leukocytes viability rates $(\mathrm{P}<0.05)$. In addition, the uppermost impairments were found when milk cells were challenged with Drug 2 and Drug 3 $(\mathrm{P}<0.05)$. Although antimicrobial activity of tested drugs was not appraised, and a single aspect of cell function was tested, we concluded that treatments 2 and 3 could damage the functionality of milk leukocytes and could provide an ineffective immunological response, in which it should be effective for a proper defense against infections of the mammary gland.

\section{Acknowledgement}

The authors thank CNPq for the undergraduate scholarship grant.

\section{References}

1. Blagitz MG, Souza FN, Santos BP, Batista CF, Parra AC, Azevedo LFF, et al. Function of milk polymorphonuclear neutrophil leukocytes in bovine mammary glands infected with Corynebacterium bovis. J Dairy Sci [Internet]. 2013 Jun;96(6):3750-7.

2. Bastos CR, Blagitz MG, Souza FN, Batista CF, Stricagnolo CR, Azedo MR, et al. Viabilidade celular, fagocitose e espraiamento de fagócitos mononucleares, e liberação de peróxido de hidrogênio por leucócitos de glândulas mamárias bovinas sadias e infectadas. Pesqui Veterinária Bras [Internet]. 2012 Sep;32(9):850-4.

3. Nickerson SC. Bovine mammary gland: structure and function; relationship to milk production and immunity to mastitis. Agri-Practice (USA). 1994;15(6):8-18.

4. Norcross NL. Specific defence mechanisms of the udder. Flem Vet J. 1996;62(1):129-39.

5. Paape M, Mehrzad J, Zhao X, Detilleux J, Burvenich C. Defense of the bovine mammary gland by polymorphonuclear neutrophil leukocytes. J Mammary Gland Biol Neoplasia. 2002 Apr;7(2):109-21.

6. Burton JL, Erskine RJ. Immunity and mastitis. Some new ideas for an old disease. Vet Clin North Am Food Anim Pract. 2003 Mar;19(1):1-45, v.

7. Owens WE, Nickerson SC, Boddie RL, Tomita GM, Ray CH. Prevalence of Mastitis in Dairy Heifers and Effectiveness of Antibiotic Therapy. J Dairy Sci. Elsevier; 2001;84(4):814-7. 
8. Shephard RW, Burman S, Marcun P. A comparative field trial of cephalonium and cloxacillin for dry cow therapy for mastitis in Australian dairy cows. Aust Vet J. 2004;82(10):624-9.

9. Bansal BK, Dhaliwal PS, Bajwa NS, Randhawa SS, Hogeveen H. Role of selective dry cow therapy in prevention of mastitis in dairy herds with high disease prevalence. In: 4th IDF International Mastitis Conference, Maastricht, The Netherlands, 12-15 June 2005. Wageningen Academic Publishers; 2005. p. 697-702.

10. Nickerson SC, Paape MJ, Dulin AM. Effect of antibiotics and vehicles on bovine mammary polymorphonuclear leukocyte morphologic features, viability, and phagocytic activity in vitro. Am J Vet Res. 1985 Nov;46(11):2259-65.

11. Dosogne H, Hoeben D, Burvenich C, Lohuis JA. Effect of cephapirin and mecillinam on the phagocytic and respiratory burst activity of neutrophil leukocytes isolated from bovine blood. J Vet Pharmacol Ther. 1998 Dec;21(6):421-7.

12. Paape MJ, Lilius EM, Wiitanen PA, Kontio MP, Miller RH. Intramammary defense against infections induced by Escherichia coli in cows. Am J Vet Res. 1996 Apr;57(4):477-82.

13. Whittem T, Whittem JH, Constable PD. Modelling the concentration-time relationship in milk from cattle administered an intramammary drug. J Vet Pharmacol Ther. 2012;35(5):460-71.

14. Batista CF, Blagitz MG, Azedo MR, Stricagnolo CR, Della Libera AMMP. Efeito de medicamentos indicados para o tratamento de mastite bovina no período seco sobre os índices de fagocitose. Ciência Anim Bras. 2009;10(2):574-80. 